\title{
Tissue type is a major modifier of the 5 -hydroxymethylcytosine content of human genes
}

\author{
Colm E. Nestor, ${ }^{1,2}$ Raffaele Ottaviano, ${ }^{1,2}$ James Reddington, ${ }^{2}$ Duncan Sproul, ${ }^{1,2}$ \\ Diana Reinhardt, ${ }^{2}$ Donncha Dunican, ${ }^{2}$ Elad Katz, ${ }^{1}$ J. Michael Dixon, ${ }^{1}$ David J. Harrison, ${ }^{1}$ \\ and Richard R. Meehan ${ }^{1,2,3}$ \\ ${ }^{1}$ Breakthrough Breast Cancer Research Unit and Division of Pathology, University of Edinburgh, Western General Hospital, Edinburgh
EH4 2XU, United Kingdom; ${ }^{2}$ MRC Human Genetics Unit, Institute of Genetics and Molecular Medicine, Western General Hospital,
Edinburgh EH4 2XU, United Kingdom
}

\begin{abstract}
The discovery of substantial amounts of 5-hydroxymethylcytosine $(5 \mathrm{hmC})$, formed by the oxidation of 5-methylcytosine $(5 \mathrm{mC})$, in various mouse tissues and human embryonic stem (ES) cells has necessitated a reevaluation of our knowledge of $5 \mathrm{mC} / 5 \mathrm{hmC}$ patterns and functions in mammalian cells. Here, we investigate the tissue specificity of both the global levels and locus-specific distribution of $5 \mathrm{hmC}$ in several human tissues and cell lines. We find that global $5 \mathrm{hmC}$ content of normal human tissues is highly variable, does not correlate with global $5 \mathrm{mC}$ content, and decreases rapidly as cells from normal tissue adapt to cell culture. Using tiling microarrays to map $5 \mathrm{hmC}$ levels in DNA from normal human tissues, we find that $5 \mathrm{hmC}$ patterns are tissue specific; unsupervised hierarchical clustering based solely on $5 \mathrm{hmC}$ patterns groups independent biological samples by tissue type. Moreover, in agreement with previous studies, we find $5 \mathrm{hmC}$ associated primarily, but not exclusively, with the body of transcribed genes, and that within these genes 5hmC levels are positively correlated with transcription levels. However, using quantitative $5 \mathrm{hmC}-\mathrm{qPCR}$, we find that the absolute levels of $5 \mathrm{hmC}$ for any given gene are primarily determined by tissue type, gene expression having a secondary influence on $5 \mathrm{hmC}$ levels. That is, a gene transcribed at a similar level in several different tissues may have vastly different levels of $5 \mathrm{hmC}$ ( $>20$-fold) dependent on tissue type. Our findings highlight tissue type as a major modifier of $5 \mathrm{hmC}$ levels in expressed genes and emphasize the importance of using quantitative analyses in the study of $5 \mathrm{hmC}$ levels.
\end{abstract}

[Supplemental material is available for this article.]

Typically, mammalian DNA methylation involves the covalent attachment of a methyl group to the 5-position of cytosine in a CpG dinucleotide by a member of the DNA methyltransferase (DNMT) family of enzymes. DNA methylation patterns are established in early development by the de novo methyltransferases, DNMT3A/B, and maintained after subsequent cell divisions by the maintenance methyltransferase, DNMT1 (Bird 2002; Wu and Zhang 2010). The ability to establish and maintain DNA methylation patterns is essential for normal development in mammals ( $\mathrm{Li}$ et al. 1992). Specifically, DNA methylation is involved in the maintenance of genome integrity by silencing transposable elements (Walsh et al. 1998), the process of X-inactivation in females (Lock et al. 1987; Sado et al. 2000), regulation of allele-specific expression at imprinted loci (Plass and Soloway 2002), and may be involved in the regulation of single-copy gene expression (Borgel et al. 2010). The genomic distribution of CpG methylation in the human genome is highly non-random; whereas the majority of CpGs are methylated, regions of high CpG density, termed CpG islands, which often colocalize with gene promoters, are typically unmethylated. How this dichotomous pattern of CpG methylation is maintained is unclear.

In a groundbreaking study, the DNA of mouse Purkinje neurons and embryonic stem (ES) cells were found to contain signifi-

\footnotetext{
${ }^{3}$ Corresponding author.

E-mail richard.meehan@hgu.mrc.ac.uk.

Article published online before print. Article, supplemental material, and publication date are at http://www.genome.org/cgi/doi/10.1101/gr.126417.111. Freely available online through the Genome Research Open Access option.
}

cant levels of the modified base 5-hydroxymethylcytosine (5hmC) (Kriaucionis and Heintz 2009). A complementary study identified the ten-eleven translocation (TET) protein, TET1, as an iron- and $\alpha$-ketoglutarate $(\alpha-\mathrm{KG})$-dependent dioxygenase responsible for catalyzing the hydroxylation of $5 \mathrm{mC}$ to $5 \mathrm{hmC}$ (Tahiliani et al. 2009). Subsequent studies have reported significant levels of $5 \mathrm{hmC}$ in many other mouse and human tissues (Globisch et al. 2010; Szwagierczak et al. 2010; Jin et al. 2011) and confirmed TET2 and TET3 as possessing enzymatic properties similar to that of TET1 (Ito et al. 2010; Koh et al. 2011). Interestingly, the genes TET1 and TET2 were first identified as common targets of mutation in Acute Myeloid Leukaemia (AML). Recently, Figueroa et al. (2010) showed that mutation of the isocitrate dehydrogenase genes IDH1 and $I D H 2$ led to the aberrant production of 2-hydroxyglutarate (2-HG), a metabolite that inhibits TET2 enzymatic activity, resulting in a hypermethylated promoter phenotype in AML tumors carrying IDH1/2 mutations. This hypermethylated promoter phenotype overlapped with AML tumors carrying a TET2 mutation only, highlighting a potential role for the TET family of proteins in the epigenetic dysregulation observed in many cancers (Figueroa et al. 2010). In addition, Tet1 knockdown in mouse ES cells resulted in de novo methylation of the transcription start site (TSS) of more than 100 genes, although the gain in $5 \mathrm{mC}$ was modest (Williams et al. 2011).

Many of the techniques commonly used to assay $5 \mathrm{mC}$, including conventional methyl-sensitive restriction digest and the widely used technique of bisulfite sequencing, are incapable of distinguishing between $5 \mathrm{mC}$ and $5 \mathrm{hmC}$ (Huang et al. 2010; Jin et al. 2010; Nestor et al. 2010). As such, the discovery of $5 \mathrm{hmC}$ 
necessitates not only its characterization in mammalian cells, but also reevaluation of previously published $5 \mathrm{mC}$ data (Dahl et al. 2011). The recent development of $5 \mathrm{hmC}$-specific antibodies and $5 \mathrm{hmC}$-sensitive restriction digest-PCR (5hmC-qPCR) assays has allowed for determination of genome-wide patterns and locusspecific amounts of $5 \mathrm{hmC}$ levels, respectively (Davis and Vaisvila 2011; Jin et al. 2011).

The biological function of $5 \mathrm{hmC}$ is unknown. However, several very recent studies of the genome-wide distribution of both 5hmC and TET1-binding in mouse ES cells have begun to illuminate potential roles of both the mark and the proteins, which in some cases may not only be separate, but conflicting. A role for $5 \mathrm{hmC}$ as an intermediate in DNA demethylation has been widely postulated (Tahiliani et al. 2009; Wu and Zhang 2010). As 5hmC is poorly recognized by DNMT1 (Valinluck and Sowers 2007), methylation can be lost passively through successive cell divisions. However, the rapid loss of $5 \mathrm{mC}$ from the paternal pro-nucleus in the zygote and in primordial germ cells has long hinted at a process of active demethylation in mammals (Mayer et al. 2000; Oswald et al. 2000; Hajkova et al. 2002). It is hypothesized that conversion of $5 \mathrm{mC}$ to $5 \mathrm{hmC}$ may serve as the first step in such a pathway by providing a substrate for downstream repair pathways such as mismatch (MMR) or base-excision repair (BER), which ultimately replace $5 \mathrm{hmC}$ with cytosine (C) (Wu and Zhang 2010). In support of this hypothesis, two recent reports have shown that the rapid loss of $5 \mathrm{mC}$ from mouse paternal pro-nuclei is accompanied by an accumulation of genome-wide $5 \mathrm{hmC}$ (Iqbal et al. 2011; Wossidlo et al. 2011). However, the failure to find many of the predicted intermediates of an active oxidative demethylation pathway by mass-spectrometry analysis of normal mouse brain tissues challenges the existence of such a mechanism (Globisch et al. 2010). The observations that $5 \mathrm{hmC}$ is enriched in the gene body of active genes in mouse cerebellum (Song et al. 2010) and cannot be bound by transcriptionally repressive methyl-CpG binding domain (MBD) proteins in vitro (Valinluck et al. 2004; Jin et al. 2010) strongly suggested a role for $5 \mathrm{hmC}$ in the regulation of transcription. Gene-body $5 \mathrm{hmC}$ levels may regulate the transcription rate by modifying the accessibility of genic chromatin to transcriptional machinery or by inhibiting binding of repressive methylCpG binding proteins (MBDs). However, work on mouse ES cells suggests that the relationship between $5 \mathrm{hmC}$ and/or TET1 with transcription is far more complex (Pastor et al. 2011; Williams et al. 2011; Wu et al. 2011a,b). TET1 enrichment was often observed at the transcription start site (TSS) of genes with high CpG density (HCP) promoters marked by the bivalent histone signature of histone 3 lysine 27 trimethylation (H3K27me3) and histone 3 lysine 4 trimethylation ( $\mathrm{H} 3 \mathrm{~K} 4 \mathrm{me} 3)$. This gene set is enriched for transcriptionally repressed developmental genes. Moreover, the repressive activity of TET1 may be independent of its catalytic role, because several genes up-regulated upon Tet1 knockdown in WT ES cells were also up-regulated in ES cells lacking DNA methylation

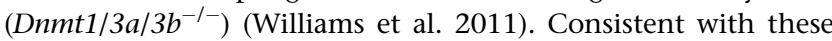
observations, $\mathrm{Wu}$ and colleagues found $5 \mathrm{hmC}$ to be enriched in the bodies of highly expressed genes and at the TSS of transcriptionally inactive genes (Wu et al. 2011a). However, two simultaneous studies failed to report a significant association between genic $5 \mathrm{hmC}$ and transcription levels or RNA polymerase II activity (Pastor et al. 2011; Williams et al. 2011).

The majority of recent genome-wide studies of $5 \mathrm{hmC}$ and TET1 have used the same model system, mouse ES cells. Thus, the nature of locus-specific patterns of $5 \mathrm{hmC}$ within and between normal tissues remains unknown. Here, we use tiling microarrays and $5 \mathrm{hmC}$-qPCR to investigate both global $5 \mathrm{hmC}$ content and locus-specific patterns of $5 \mathrm{hmC}$ in several normal human tissues. We find that unlike $5 \mathrm{mC}$, global $5 \mathrm{hmC}$ content varies markedly between tissues and does not correlate with global $5 \mathrm{mC}$ content. Furthermore, the global $5 \mathrm{hmC}$ content of cell lines is markedly reduced compared with levels in the corresponding normal tissues. Significantly, we note that TET1/2/3 gene expression and consequently $5 \mathrm{hmC}$ content is rapidly and significantly reduced upon adaptation of cells from normal human tissue to cell culture. Using an $5 \mathrm{hmC}$-specific antibody and tiling microarrays to profile locusspecific patterns of $5 \mathrm{hmC}$, we found that $5 \mathrm{hmC}$ patterns are tissuespecific; allowing clustering of similar tissues based on $5 \mathrm{hmC}$ profiles alone. In addition, using RNA-seq data for normal human tissues, $5 \mathrm{hmC}$ was found to be enriched in the gene bodies of active genes, and the level of enrichment was positively correlated with gene expression levels. Significantly, however, we also find that for any given expressed gene, tissue type, not transcription level, is the major modifier of absolute levels of $5 \mathrm{hmC}$.

\section{Results}

\section{Global $5 \mathrm{hmC}$ content of human tissues is variable and does not correlate with total $\mathrm{mC}$ content or TET gene expression}

PCR products of the mouse Tex19.1 promoter in which each cytosine was either unmethylated $(\mathrm{C})$, methylated $(5 \mathrm{mC})$, or hydroxymethylated $(5 \mathrm{hmC})$ were used to test the sensitivity and specificity of both the $\alpha-5 \mathrm{mC}$ and $\alpha-5 \mathrm{hmC}$ antibodies in immuno dot-blot assays. Both antibodies exhibited specificity to their respective marks and no cross-reactivity was observed, even at higher concentrations of DNA (Fig. 1A). The dynamic range of detection of $5 \mathrm{hmC}$ implies that this assay can be usefully employed to determine differences in the $5 \mathrm{hmC}$ content of different genomic DNA samples.

Immuno dot-blots of DNA from eight normal human tissues and one human embryonic stem cell (hESC) line (Shef-6) revealed large inter-tissue variation in global $5 \mathrm{hmC}$ levels (Fig. 1B). In agreement with previous studies, human brain had the highest global levels of both $5 \mathrm{hmC}$ and $5 \mathrm{mC}$ (Song et al. 2010). Quantification of spot intensity by densitometric analysis further emphasized the scale of variation in global $5 \mathrm{hmC}$ between tissues. For example, levels in brain were about four times greater than those in the next highest tissue, breast, and more than 1000 times greater than the levels in blood or hESCs (Fig. 1C). The variation in intertissue global $5 \mathrm{hmC}$ levels contrasted strikingly with global $5 \mathrm{mC}$ levels, which varied little between tissues. Whereas the dot-blot assay could robustly detect the large inter-tissue differences observed in global $5 \mathrm{hmC}$ levels, relative inter-tissue differences in $5 \mathrm{mC}$ were more difficult to quantify with confidence due to the small intertissue differences in global $5 \mathrm{mC}$ levels observed. To confirm the apparent lack of association between global $\mathrm{mC}$ and $\mathrm{hmC}$ levels determined by dot-blotting, the inter-tissue differences in $5 \mathrm{hmC}$ determined here were compared with previously published global $5 \mathrm{mC}$ levels quantified by high-performance liquid chromatography (HPLC) (Ehrlich et al. 1982; Weisenberger et al. 2005). No significant correlation was found between global $5 \mathrm{hmC}$ and $5 \mathrm{mC}$ levels (Spearman's $r h o=-0.42 ; P=0.35$ ) (Fig. 1D). Interestingly, broadly similar patterns of inter-tissue global $5 \mathrm{mC}$ and $5 \mathrm{hmC}$ levels were conserved in mouse; brain and liver being highly enriched, whereas blood, spleen, and ES cells were relatively depleted of $5 \mathrm{hmC}$ (Fig. 1E).

To test the association between TET gene expression and global $5 \mathrm{hmC}$ content, we determined the relative expression level

\section{Genome Research}


A

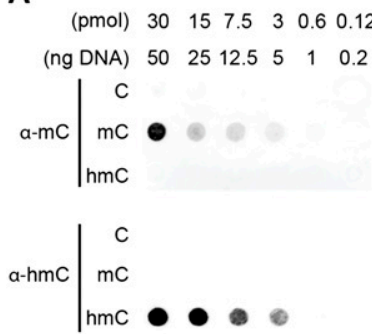

B

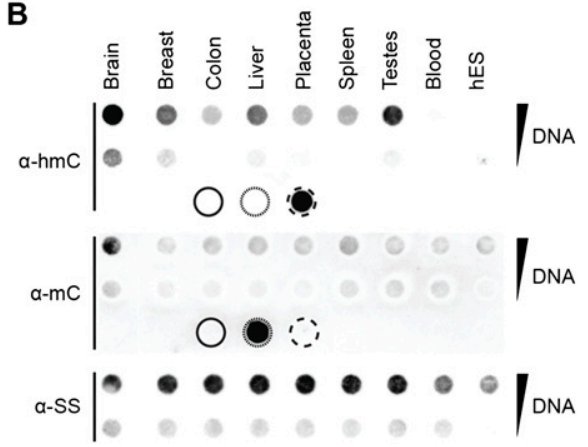

C

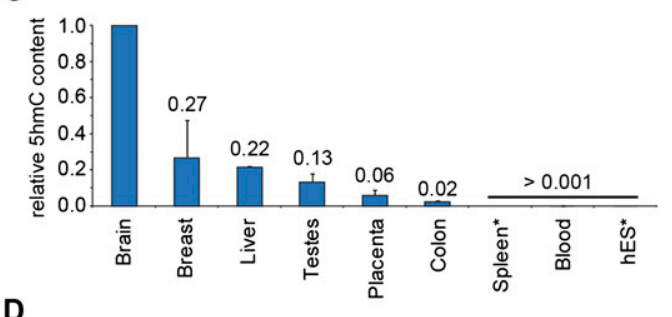

D

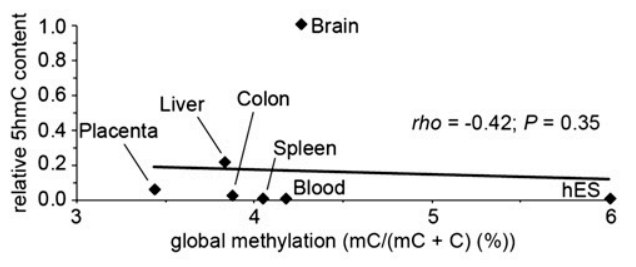

E

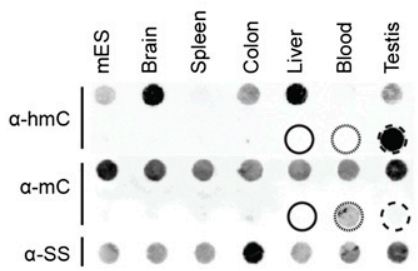

Figure 1. Marked inter-tissue differences in global $5 \mathrm{hmC}$ levels. (A) Dot-blots of decreasing amounts of a PCR product of the mouse Tex 19 promoter sequence in which all cytosines are either unmodified $(C)$, methylated $(5 \mathrm{mC})$, or hydroxymethylated $(5 \mathrm{hmC})$, were probed with $\alpha-5 \mathrm{hmC}$ and $\alpha-5 \mathrm{mC}$ antibodies. The $\alpha-5 \mathrm{hmC}$ and $\alpha-5 \mathrm{mC}$ antibodies are specific for their respective marks. (B) Duplicate dot-blots of DNA from human tissues and ES cells probed with antibodies specific to $5 \mathrm{hmC}$ or $5 \mathrm{mC}$ show that global $5 \mathrm{hmC}$ levels vary markedly between normal human tissues. An $\alpha$-ssDNA antibody was used to control for loading; $500 \mathrm{ng}$ and $100 \mathrm{ng}$ were loaded in the upper and lower lanes, respectively. Ten nanograms of amplified mouse Tex19.1 promoter was used as a control; (solid circle) unmethylated DNA; (dotted circle) methylated DNA; (dashed circle) hydroxymethylated DNA. (C) Intertissue differences in global $5 \mathrm{hmC}$ levels as determined by densitometric analysis of dot-blots shown in panel $B$. $5 \mathrm{hmC}$ values were normalized to an ssDNA loading control and scaled relative to brain. Values are the means of two independent biological replicates. Spleen and ES values represent single measurements. $(D)$ A scatterplot showing a lack of correlation between global $5 \mathrm{mC}$ and $5 \mathrm{hmC}$ values for seven samples. $5 \mathrm{mC}$ values were obtained from previously published HPLC analyses of global $5 \mathrm{mC}$ content in human tissues (Ehrlich et al. 1982; Weisenberger et al. 2005). (E) Duplicate dot-blots of DNA from mouse tissues and ES cells probed with antibodies specific to $5 \mathrm{hmC}$ or $5 \mathrm{mC}$ show that global $5 \mathrm{hmC}$ levels vary markedly between normal mouse tissues. An $\alpha$-ssDNA antibody was used to control for loading. Ten nanograms of amplified mouse Tex19.1 promoter was used as a control; (solid circle) unmethylated DNA; (dotted circle) methylated DNA; (dashed circle) hydroxymethylated DNA.

of all three TET genes in 20 human tissues and human ES cells (Supplemental Fig. S2A). Each tissue cDNA sample was generated from RNAs pooled from at least three different individuals. The relative expression of TET2 and TET3 between tissues was highly similar to that reported in mouse (Ito et al. 2010). Human ES cells are distinguished by their relative lack of TET2 and TET3 expression, suggesting that TET1 may be the primary dioxygenase responsible for generation of $5 \mathrm{hmC}$ in these cells. However, human TET1 expression was just twofold higher in ES cells compared with average expression in somatic tissues. This is markedly lower than the 10-fold difference in Tet1 expression observed between ES cells and somatic tissues in mouse (Ito et al. 2010). Our observation of TET1 expression in human tissues is consistent with a previous analysis of TET1/2/3 gene expression in 24 human tissues that reported TET1 expression in half $(12 / 24)$ of the tissues assayed (Lorsbach et al. 2003). Interestingly, TET1/2/3 gene expression did not correlate with relative global $5 \mathrm{hmC}$ content (Supplemental Fig. S2B).

\section{Cell culture results in a dramatic reduction of global $5 \mathrm{hmC}$ levels}

Epigenetic dysregulation, including promoter hypermethylation and genome-wide hypomethylation, is a hallmark of many cancers
(Esteller 2007). Moreover, several recent studies have reported a direct link between TET inhibition and aberrant promoter hypermethylation in AML (Figueroa et al. 2010; Xu et al. 2011). Thus, we determined if global $5 \mathrm{hmC}$ levels in cell culture models of several human cancers differed from that observed in their corresponding non-cancerous tissues of origin.

We observed much lower global $5 \mathrm{hmC}$ in eight breast cancer cell lines and one primary human mammary epithelial cell (HMEC) line relative to normal breast tissue (Fig. 2A,B). This reduction of global $5 \mathrm{hmC}$ in human breast cell lines was mirrored by significantly reduced levels of transcripts for all three TET genes relative to levels in normal breast tissue (Fig. 2C). A similar reduction in global $5 \mathrm{hmC}$ levels was observed in both colon and liver cancer cell lines relative to levels in the corresponding non-cancerous tissues (Fig. 2D). Interestingly, DNA obtained from a primary HMEC line $1 \mathrm{wk}$ after establishment from normal breast tissue also showed a dramatic reduction in both global $5 \mathrm{hmC}$ content and TET gene expression, suggesting that conversion to cell culture may be sufficient to effect a global reduction in $5 \mathrm{hmC}$ levels (Fig. 2A-C). This marked reduction in TET1/2/3 gene expression in culture was not observed between normal breast tissue and breast tumors in three previously published independent microarray studies, suggesting that the observed TET gene downregulation in culture may not be a cancer-associated process 
A

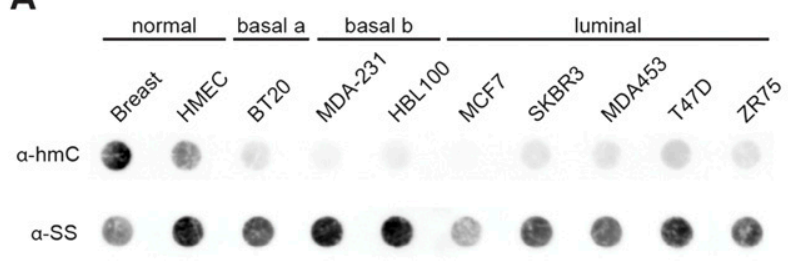

B

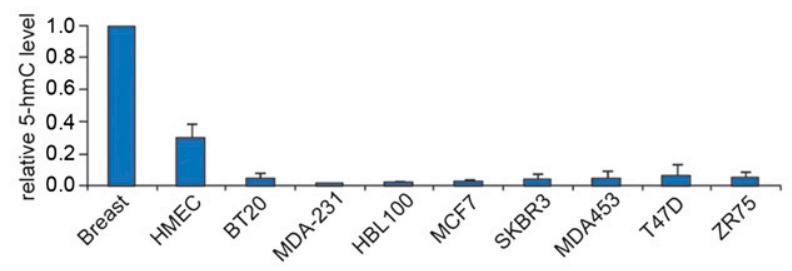

C

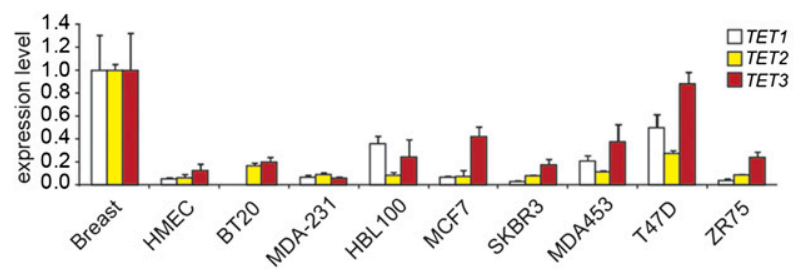

D

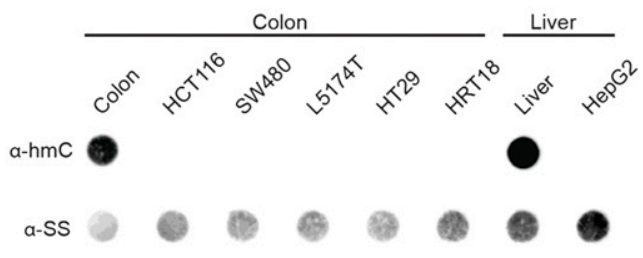

E

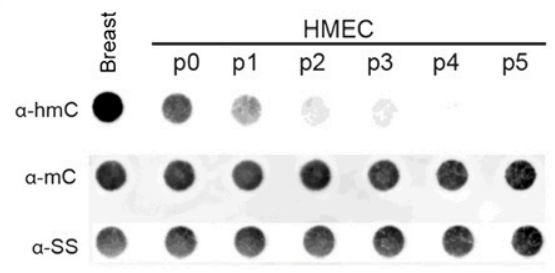

Controls:

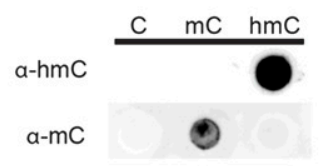

Figure 2. Reduced global $5 \mathrm{hmC}$ levels and $T E T 1 / 2 / 3$ gene expression in human cell lines. $(A)$ Duplicate dot-blots of DNA (500 ng) from normal human breast tissue, a primary mammary epithelial cell line from non-cancerous tissue, and eight breast cancer cell lines probed with antibodies specific to 5 hmC or ssDNA illustrate that global $5 \mathrm{hmC}$ levels are reduced in the DNA of primary and cancer cell lines relative to normal breast. ( $B$ ) Inter-sample differences in global $5 \mathrm{hmC}$ levels by densitometric analysis of dot-blots shown in panel $A$. $5 \mathrm{hmC}$ values were normalized to the ssDNA loading control and scaled relative to normal breast DNA. Values are the means of two technical replicates. (C) RT-qPCR analysis of expression levels of TET1, TET2, and TET3 in normal human breast tissue, a primary mammary epithelial cell line, and eight breast cancer cell lines. Expression levels were normalized to GAPDH expression, and expression levels in normal human breast set to 1 . Error bars represent the SD of two technical replicates. (D) Duplicate dot-blots of DNA (500 ng) from normal human colon and liver tissue and six cancer cell lines probed with antibodies specific to $5 \mathrm{hmC}$ or ssDNA illustrate that global $5 \mathrm{hmC}$ levels are also reduced in the DNA of colon and liver cancer cell lines relative to normal tissue. (E) Duplicate dot-blots of DNA (500 ng) from normal human breast tissue, and the primary mammary epithelial cell line derived from that tissue probed with antibodies specific to $5 \mathrm{hmC}$, $5 \mathrm{mC}$, or ssDNA show that global levels of $5 \mathrm{hmC}$, but not $5 \mathrm{mC}$, are gradually reduced upon transformation of normal breast tissue to cell culture. Ten nanograms of amplified mouse Tex19.1 promoter in which all cytosines were either unmodified (C), methylated (mC), or hydroxymethylated (hmC), was used as a control.

(Supplemental Fig. S3) (Richardson et al. 2006; Turashvili et al. 2007; Chen et al. 2010). To further investigate this hypothesis, we cultured cells from normal human breast tissue and analyzed the changes in both global $5 \mathrm{mC}$ and $5 \mathrm{hmC}$ levels over time. Rapid loss of $5 \mathrm{hmC}$ was apparent after $1 \mathrm{wk}$ in culture (1 passage $\sim 7 \mathrm{~d}$ ), and global $5 \mathrm{hmC}$ levels continued to decrease with each passage of the cells. In stark contrast, global $5 \mathrm{mC}$ levels remained unchanged, suggesting that the loss of $5 \mathrm{hmC}$ was not solely due to a concomitant loss of $5 \mathrm{mC}$ (Fig. 2E).

\section{Locus-specific mapping of $5 \mathrm{hmC}$ in DNA from normal human tissues}

The marked difference in global $5 \mathrm{hmC}$ levels observed between normal human tissues could reflect differences in locus-specific patterns of $5 \mathrm{hmC}$. A recent study of genome-wide $5 \mathrm{hmC}$ in mouse ES cell DNA found that $5 \mathrm{hmC}$ immuno-precipitation combined with genome-wide tiling microarrays could consistently and robustly identify peaks of $5 \mathrm{hmC}$ in the mouse genome (Wu et al. 2011a). Here we used a combination of tiling microarrays and $5 \mathrm{hmC}$-sensitive restriction digest-qPCR (hmC-qPCR) to determine locus-specific $5 \mathrm{hmC}$ patterns in several normal human tissues. As recent studies have revealed that both intra- and intergenic regions of the mouse genome can contain high levels of $5 \mathrm{hmC}$, we used tiling microarrays covering the ENCODE regions selected for their biological significance, including the HOXA cluster, $H B B, C F T F R$, and APO cluster. The features represented on each array are listed in Supplemental Table S3.

Using a candidate approach, we identified the promoter of TEX14 and a differentially methylated region (DMR) of the H19 gene as enriched for $5 \mathrm{hmC}$, whereas LINE-1 elements and the promoter of GAPDH were relatively depleted. qPCR of these loci were used to validate all hydroxymethylated DNA immuno-precipitation (5hmC-IP) assays (Supplemental Fig. S4A).

Unsupervised hierarchical clustering of $5 \mathrm{hmC}$ enrichment values $\left[\log _{2}(\mathrm{input} / \mathrm{IP})\right]$ for all 72,000 probes on each array clustered samples by tissue type, confirming that patterns of $5 \mathrm{hmC}$ are tissue-specific and that inter-tissue variation in $5 \mathrm{hmC}$ patterns is greater than inter-individual variation (Fig. 3A,B).

Peaks of $5 \mathrm{hmC}$ enrichment were defined as any five consecutive probes in which a minimum of four probes had an enrichment score above the 75th percentile, yielding a false discovery rate $(\mathrm{FDR})<0.05$. We term probes assigned to $5 \mathrm{hmC}$ peaks "peakprobes." Subsequently, using gene models from the RefSeq database, each probe was classified according to its genic location-

\section{Genome Research}


A

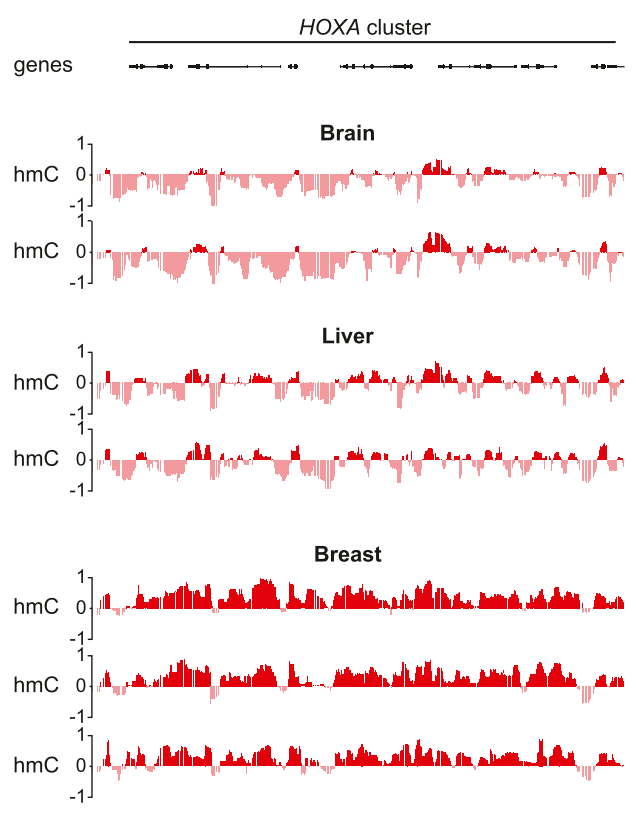

B

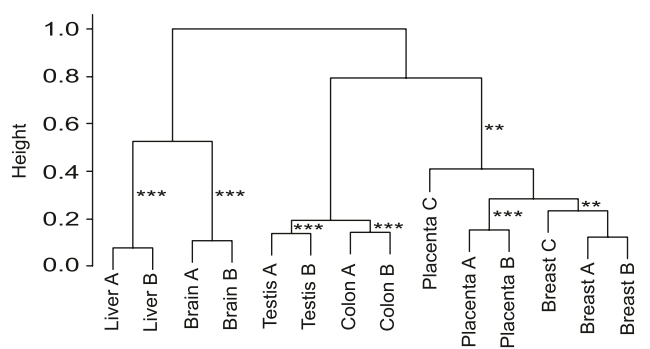

Figure 3. Genomic patterns of $5 \mathrm{hmC}$ enrichment are tissue-specific. $(A)$ Shown are the patterns of $5 \mathrm{hmC}$ enrichment $\left[\log _{2}\right.$ (input/IP)] across the HOXA cluster for multiple replicates of multiple tissues. (B) A dendrogram derived from unsupervised hierarchical consensus clustering of 14 human DNA samples based on $5 \mathrm{hmC}$ enrichment levels for all 72,000 probes on each tiling microarray. Samples cluster by tissue type. AU (approximately unbiased) $P$-value of robustness of each cluster; $\left.\left(^{\star \star}\right) P>0.01 ;{ }^{(\star *}\right) P>$ 0.001 .

promoter, intragenic, downstream, or intergenic, as illustrated in Figure 4A (upper panel). Note that because repetitive sequences are typically not represented on tiling microarrays, only the non-repetitive portion of each genic location is assessed here. Consistent with previous studies in mouse ES cells, the genic distribution of peak probes differed significantly from that expected by chance $\left(\chi^{2}\right.$-test; $\left.P<0.001\right)$ being enriched in intragenic regions and promoters (Fig. 4A, lower panel). However, it is interesting to note that $\sim 25 \%$ of $5 \mathrm{hmC}$ peaks are not located within annotated genes and their proximal flanking sequences. To further investigate the observed association of $5 \mathrm{hmC}$ enrichment and gene bodies, we analyzed the overlap between $5 \mathrm{hmC}$ peak-probes and previously published total RNA-sequencing reads for normal human brain, breast, colon, liver, and testis (Ramskold et al. 2009). We find that peak-probes preferentially colocalize with RNA-seq reads in all tissues (Fig. 4B) and that the $5 \mathrm{hmC}$ level of probes is positively correlated with transcription, as measured by the number of overlapping RNA-seq reads (Fig. 4C). Interestingly, although the association of $5 \mathrm{hmC}$ levels with gene transcription within tissues is striking at some loci (Fig. 4D; Supplemental Fig. S5), it does not explain the patterns of $5 \mathrm{hmC}$ observed at many other loci (Supplemental Fig. S6). Indeed, although significantly correlated, transcription (number of overlapping reads) explained $<1 \%$ (i.e., brain; $r^{2}=0.0025, P=0$ ) in the variation in $5 \mathrm{hmC}$ values in each tissues assayed

As tiling microarrays are limited in their ability to represent non-unique sequences, we determined the $5 \mathrm{hmC}$ enrichment of several repetitive elements by $5 \mathrm{hmC}$-IP followed by qPCR. SINE elements (Alu), LINE-1 elements, and satellite sequences (Sat2 and Sat $\alpha$ ) were all relatively depleted of $5 \mathrm{hmC}$ in both normal tissues and cancer cell lines (Supplemental Fig. S7A). Thus, whereas much of the total $5 \mathrm{mC}$ content of a normal human genome is found in the repetitive fraction, $5 \mathrm{hmC}$ appears largely occluded from repeat sequences. As "repeats" may comprise $>50 \%$ of the human genome and are usually methylated in normal somatic tissue, the relative lack of global $5 \mathrm{hmC}$ compared with global $5 \mathrm{mC}$ in reports for most normal mouse tissues may simply reflect a restriction of $5 \mathrm{hmC}$ to unique, transcribed sequences (Weisenberger et al. 2005; Kriaucionis and Heintz 2009; Globisch et al. 2010).

\section{Tissue type, not transcription level, is the major modifier} of $5 \mathrm{hmC}$ levels in genes

Whereas antibody-based enrichment of 5hmC-containing DNA fragments allows for characterization of genome-wide $5 \mathrm{hmC}$ patterns, it is difficult to relate the enrichment values obtained to absolute levels of $5 \mathrm{hmC}$, which can also be compromised by the effects of DNA sequence composition on antibody affinity. We used $5 \mathrm{hmC}$-sensitive restriction digest-qPCR (hmC-qPCR) to determine absolute $5 \mathrm{hmC}$ levels at 12 loci across (1) the HOXA cluster, which shows marked differences in $5 \mathrm{hmC}$ profiles between tissues, and (2) the $H 19$ locus, which is among the most enriched regions assayed in all tissues (Supplemental Figs. S5, S6). An outline of the assay and sample calculations are presented in Supplemental Figure S1. We tested the accuracy of the assay by spiking each genomic sample with synthetic 100-bp DNA templates containing a single MspI site in which the internal cytosine was either unmodified (C), methylated $(5 \mathrm{mC})$, or hydroxymethylated $(5 \mathrm{hmC})$. Different ratios of each template type were added to different reactions. The expected $\% 5 \mathrm{hmC}$ and experimentally determined $\% 5 \mathrm{hmC}$ levels were highly significantly correlated (Pearson's correlation; $r=0.96, P>0.0001$ ) over 10 independent experiments (Supplemental Fig. S8A). In addition, technical and biological replicates of both liver and brain samples were highly significantly correlated over seven loci tested, showing that the results obtained are highly reproducible (Supplemental Fig. S8B,C).

Marked variation in locus-specific $5 \mathrm{hmC}$ content was observed between tissues; whereas the $5 \mathrm{hmC}$ content of loci in the gene body of $H 19$ varied between $37 \%$ and $70 \%$ in brain DNA, values of just $0.9 \%-4.3 \%$ were observed in blood (Table 1 ). In agreement with values obtained from tiling microarrays, each tissue had consistently higher levels of $5 \mathrm{hmC}$ at loci in the H19/IGF2 region than those in the HOXA cluster, and genic loci in both regions showed higher levels of $5 \mathrm{hmC}$ than non-genic loci (Supplemental Fig. S9A,B). However, no significant correlation between $5 \mathrm{hmC}$ enrichment values determined on the microarray and those determined by 5 hmC-qPCR was observed over the 12 loci tested. The absence of significant correlation is not entirely unexpected given that $5 \mathrm{hmC}$ enrichment values on the microarrays were determined by immuno-precipitation of large DNA fragments (200- 
A
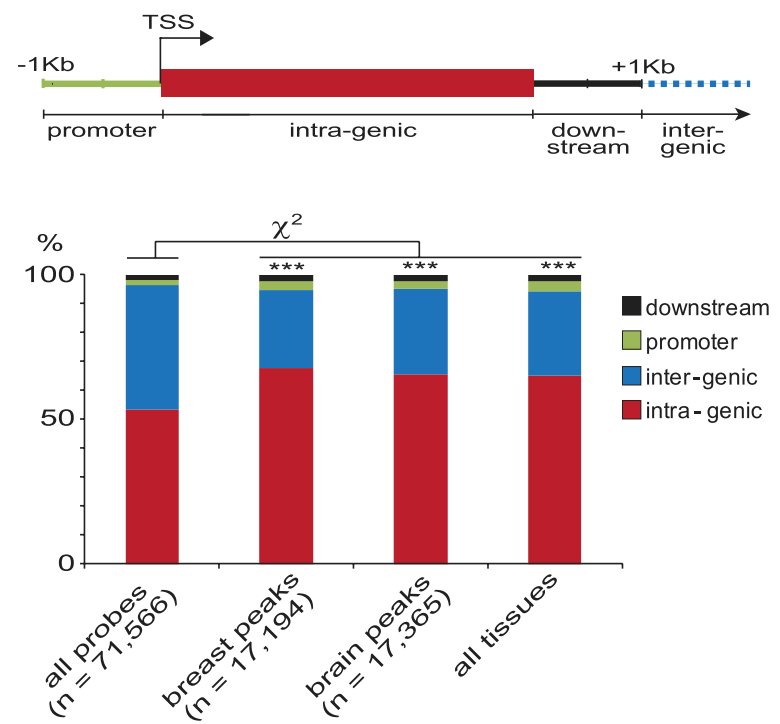

C

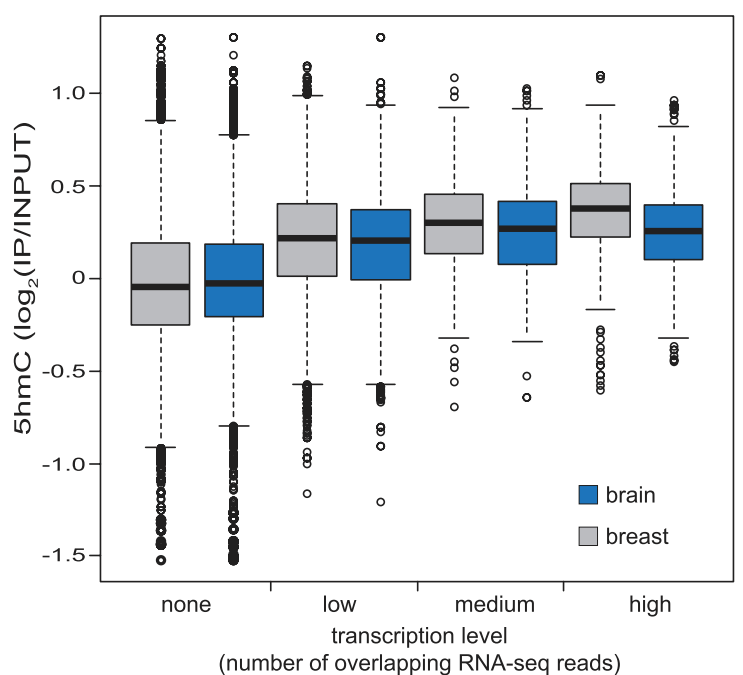

B

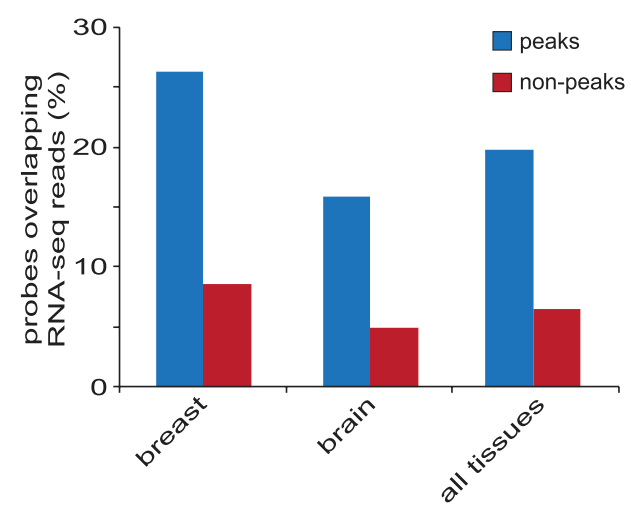

D Brain

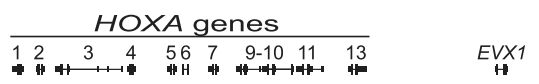

$\underset{H}{E V X 1}$

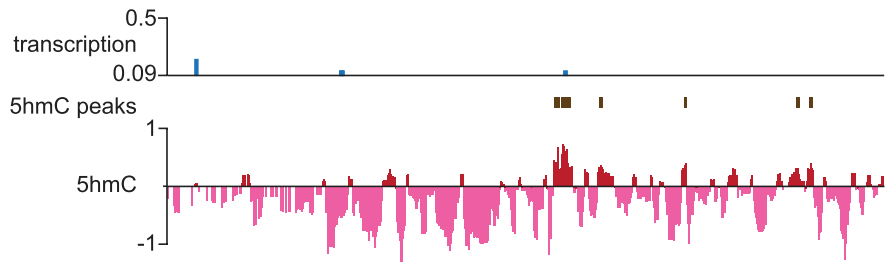

Breast

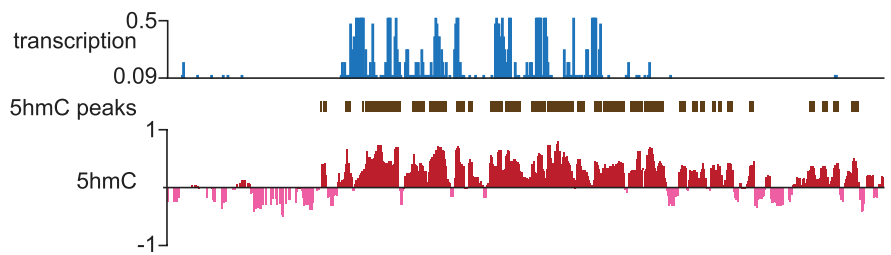

Figure 4. $5 \mathrm{hmC}$ is enriched in transcribed regions. (A) Diagram illustrating the defined genomic regions that are assayed for $\% 5 \mathrm{hmC}$ enrichment. All probes found within peaks of $5 \mathrm{hmC}$ enrichment were classified according to their genic location. The bar chart below illustrates that probes within peaks of $5 \mathrm{hmC}$ ("peak-probes") are enriched in intragenic regions in brain and breast tissues. See text for definition of $5 \mathrm{hmC}$ peaks. (B) Bar chart illustrating that the peak-probes associate with regions of active transcription in brain and breast. The percentage of probes overlapping RNA-sequencing reads for each tissue is shown. (C) Box plot showing that $5 \mathrm{hmC}$ levels increase with steady-state transcript levels. Each probe was classified according to its number of overlapping RNA-sequencing reads for brain and breast; none $=0$, low $=1$, medium $=1-5$, high $>5$. $(D)$ The presence of $5 \mathrm{hmC}$ is associated with transcription. The HOXA cluster is transcribed and marked with $5 \mathrm{hmC}$ in breast, whereas transcription and $5 \mathrm{hmC}$ appear absent in brain. Schematic representation of both the $5 \mathrm{hmC}$ and RNA-sequencing profile of the HOXA cluster is shown; the figure is adapted from the UCSC Genome Browser. Transcription values are given in reads per million (RPM).

$1000 \mathrm{bp}$ ) potentially containing numerous CpG dinucleotides, whereas $5 \mathrm{hmC}$-qPCR evaluates a single MspI locus within that fragment, the $5 \mathrm{hmC}$ content of which may differ markedly from that of the fragment as a whole. As only 12 loci were tested and considerable variation between the microarray and $5 \mathrm{hmC}$-qPCR was expected, we hypothesized that assaying additional loci would result in significant association between the two techniques. Ten additional loci were assayed by $5 \mathrm{hmC}-\mathrm{qPCR}$ in the brain and liver samples. The values from the microarray and $5 \mathrm{hmC}$-qPCR were now significantly correlated for liver (Pearson's correlation coefficient; $r=0.53, P=0.01$ ) and approaching significance for brain
(Pearson's correlation coefficient; $r=0.42, P=0.051$ ) samples (Supplemental Fig. S8D).

Unsupervised hierarchical clustering of $5 \mathrm{hmC}$ levels at 12 loci in six tissues resulted in grouping the samples into two clusters corresponding to loci with high levels of $5 \mathrm{hmC}$ (the "HIGH" cluster; median $5 \mathrm{hmC}$ content $=17.2 \%$ ) and those with lower levels of $5 \mathrm{hmC}$ (the "LOW" cluster; median $5 \mathrm{hmC}$ content $=$ $2.2 \%)$. Consistent with the results obtained from the microarrays, the HIGH cluster consisted entirely of genic MspI sites, primarily from the H19/IGF2 locus, whereas the LOW cluster consisted of MspI sites from the HOXA cluster and non-genic MspI sites from

\section{Genome Research}


Table 1. $5 \mathrm{hmC}$ content (\%) at 12 loci in six normal human tissues determined by $5 \mathrm{hmC}$-qPCR (EpiMark, NEB)

\begin{tabular}{lcccccc}
\hline Locus & Brain A & Breast A & Liver A & Placenta A & Testis B & Blood A \\
\hline H19 genic 3 & 69.7 & 22.3 & 24.7 & 2.8 & 14.1 & 1.3 \\
H19 genic 4 & 47.8 & 37.4 & 10.6 & 18.7 & 32.0 & 4.3 \\
IGF2 genic 1 & 43.5 & 14.4 & 16.8 & 27.0 & 47.1 & 2.7 \\
H19 genic 1 & 36.7 & 11.8 & 14.8 & 13.0 & 10.6 & 0.9 \\
HOXA6 intron & 36.2 & 59.6 & 27.2 & 17.5 & 15.4 & 1.7 \\
H19 intergenic & 13.4 & 1.2 & 4.4 & 1.7 & 0.9 & $-0.4^{2}$ \\
HOXA intergenic & 10.6 & 3.7 & $-1.7^{2}$ & $-0.2^{2}$ & 0.5 & 0.0 \\
HOXA6 exon & 9.1 & 3.9 & 4.3 & 7.4 & 1.4 & $-1.4^{2}$ \\
H19 promoter & 6.8 & 16.5 & 12.2 & 0.3 & 4.5 & 1.4 \\
HOXA7 intron & 2.6 & 8.8 & 3.7 & 10.1 & 4.5 & - \\
HOXA intergenic & 0.8 & 4.2 & 1.1 & 2.9 & 0.5 & 2.2 \\
HOXA7 exon & $-2.8^{\text {a }}$ & 2.9 & 0.1 & 0.4 & 1.9 & 0.3 \\
\hline
\end{tabular}

All values are single measurements determined by $5 \mathrm{hmC}$-qPCR (EpiMark, NEB). See Supplemental Figure S1 for experimental outline.

${ }^{a}$ Negative values were artificially set to 0.1 in analyses and plotting.

the H19/IGF2 cluster (Fig. 5A). Moreover, a heat map of the clustered samples revealed a striking difference in absolute levels of $5 \mathrm{hmC}$ at the same loci between tissues (Fig. 5A). The inter-tissue variation in $5 \mathrm{hmC}$ levels was particularly evident at loci with higher $5 \mathrm{hmC}$ content, the HIGH cluster, with large, highly significant (Mann-Whitney $U$-test, $P<0.01$ ) differences between tissues (Fig. $5 \mathrm{~B}$ ). Indeed, average $5 \mathrm{hmC}$ values in brain were more than 20 -fold higher than those observed in blood.

As the pattern of inter-tissue differences in absolute $5 \mathrm{hmC}$ content appeared similar to those previously determined for global $5 \mathrm{hmC}$ levels (Fig. 1C), we investigated the relationship between global $5 \mathrm{hmC}$ levels and those determined by locus-specific $5 \mathrm{hmC}$ qPCR. We found that global $5 \mathrm{hmC}$ levels correlated significantly with $5 \mathrm{hmC}$ levels determined for the HIGH cluster loci, LOW cluster loci, and all loci combined (Fig. 5C). Thus, although we found a small, but significant correlation between transcript levels and $5 \mathrm{hmC}$ levels within tissues, transcript levels alone could explain $<1 \%$ of the variation in $5 \mathrm{hmC}$ levels as determined by tiling microarray (i.e., brain; $r^{2}=0.0025$ ), whereas relative global $5 \mathrm{hmC}$ levels determined by dot-bot (Fig. 1C) could explain $>85 \%$ of the observed inter-tissue variation in $5 \mathrm{hmC}$ levels determined by 5hmC-qPCR at all loci $\left(r^{2}=0.85\right)$ (Fig. 5C).

As the observed inter-tissue differences in absolute $5 \mathrm{hmC}$ content could be explained by large inter-tissue variation in gene expression, we tested the association of inter-tissue expression and $\% 5 \mathrm{hmC}$ for the $H 19$ and IGF2 loci and found no significant association (Fig. 5D). A similar absence of association was found for HOXA6 (Spearman's rho $=0.5, P=0.45$ ) and HOXA7 (Spearman's $r h o=0.1, P=0.95)$. In a recent study, eight CpGs in the gene bodies of the EGFR and VANGL1 genes were assayed by $5 \mathrm{hmC}$-qPCR in four human tissues (brain, heart, spleen, and liver) and HeLa cells (Kinney et al. 2011). We determined the relative expression of EGFR and VANGL1 in these tissues by quantitative RT-PCR and, again, found no correlation between expression and $5 \mathrm{hmC}$ content of the gene body of either the EGFR (Spearman's $r h o=-0.1, P=$ 0.95 ) or VANGL1 (Spearman's rho $=-0.3, P=0.68$ ) gene (Supplemental Fig. S8E). Again, brain contained the highest levels of $5 \mathrm{hmC}$ and HeLa cells the least. Thus, these independently determined $5 \mathrm{hmC}$ data are completely consistent with our observation that tissue type is a major modifier of $5 \mathrm{hmC}$ content of genes in humans and that inter-tissue $5 \mathrm{hmC}$ levels show no clear association with gene transcription.

\section{Discussion}

The discovery of 5-hydroxymethylation of cytosine as an abundant epigenetic mark in mammalian genomes has begun to redefine the field of DNA methylation and our interpretation of DNA methylation data past and present, most of which does not distinguish between canonical $5 \mathrm{mC}$ and $5 \mathrm{hmC}$ (Nestor et al. 2010). Using immuno-precipitation of DNA with a $5 \mathrm{hmC}$-specific antibody, a plethora of recent studies have begun to describe the genomic location of $5 \mathrm{hmC}$ and the potential function of both the mark and the TET enzymes that catalyze its generation from $5 \mathrm{mC}$ (Ficz et al. 2011; Pastor et al. 2011; Williams et al. 2011; Wu et al. 2011a,b). All have reported the preferential genic localization of both TET1 and $5 \mathrm{hmC}$ in mouse ES cells; however, any correlation between $5 \mathrm{hmC}$ and transcription levels is less clear. Unexpectedly, a small set of genes were up-regulated in knockdowns of TET1 in both wild-type mouse ES cells and mES cells lacking DNA methylation, suggesting a role for TET1 in transcriptional repression, which is independent of its catalytic activity. However, most recent genome-wide studies have performed very similar experiments, and all in the same model system, namely, mouse ES cells. A single study of human brain frontal lobe tissue similarly reported an association of $5 \mathrm{hmC}$ with genic regions and a positive correlation between gene-body $5 \mathrm{hmC}$ enrichment and transcription level (Jin et al. 2011). However, because this study examined only one tissue type and was restricted to promoter regions of genes, our knowledge of $5 \mathrm{hmC}$ patterns within and between normal mammalian tissues remains basic.

Here, we present the first systematic study of both global and locus-specific patterns of $5 \mathrm{hmC}$ in normal human tissues and both cancer- and non-cancer-derived cell lines. Importantly, in addition to immuno-precipitation-based assays of $5 \mathrm{hmC}$ content, we use sensitive $5 \mathrm{hmC}$-qPCR to quantify absolute levels of $5 \mathrm{hmC}$ at several loci in numerous tissues. We report large differences in global $5 \mathrm{hmC}$ in normal human tissues, consistent with reports of global $5 \mathrm{hmC}$ in mouse tissues (Kriaucionis and Heintz 2009). The intertissue difference in global $5 \mathrm{hmC}$ is striking, brain DNA containing $>20$ times the $5 \mathrm{hmC}$ of blood DNA. Indeed, although we show that transcription level correlates weakly with $5 \mathrm{hmC}$ levels within tissues, tissue type, and thus global $5 \mathrm{hmC}$ content is a far more powerful predictor of the $5 \mathrm{hmC}$ content in genes (Fig. 5C). Our failure to find significant correlation between gene expression and $5 \mathrm{hmC}$ content between tissues is surprising (Fig. 5D) and suggests that factors other than transcription are the major modifiers of genic $5 \mathrm{hmC}$ content. In addition, because the observed reduction in $5 \mathrm{hmC}$ across all tissues was broadly conserved at all loci tested, inter-tissue differences in global $5 \mathrm{hmC}$ are most likely due to a largely equal reduction in $5 \mathrm{hmC}$ content across the genome, as opposed to disproportionate loss at certain genomic elements (i.e., repeats).

$5 \mathrm{hmC}$ is widely presumed to be an intermediate in a process of DNA demethylation, either active or passive. Assuming a model of passive demethylation, $5 \mathrm{hmC}$ loss resulting from failure to maintain the mark after DNA replication, one would predict that tissues with a relatively low proliferation rate (i.e., brain) would 
A

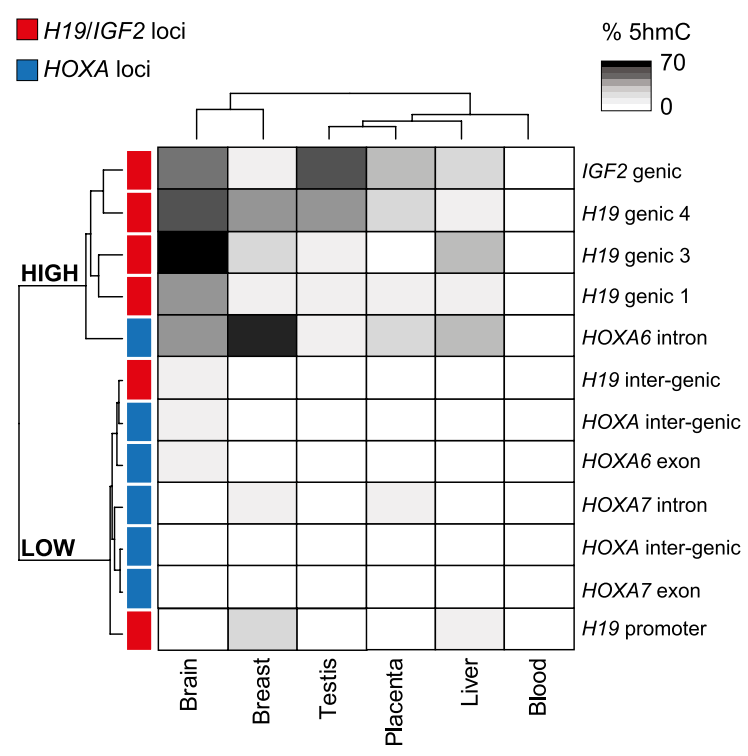

B

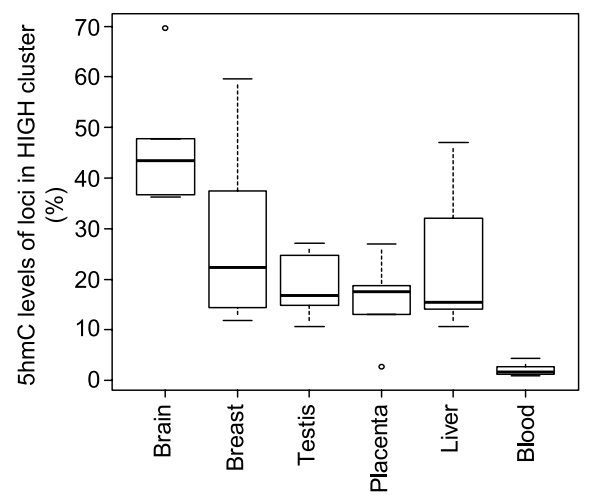

C

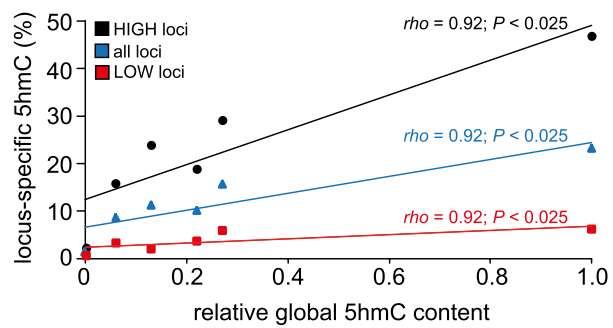

D

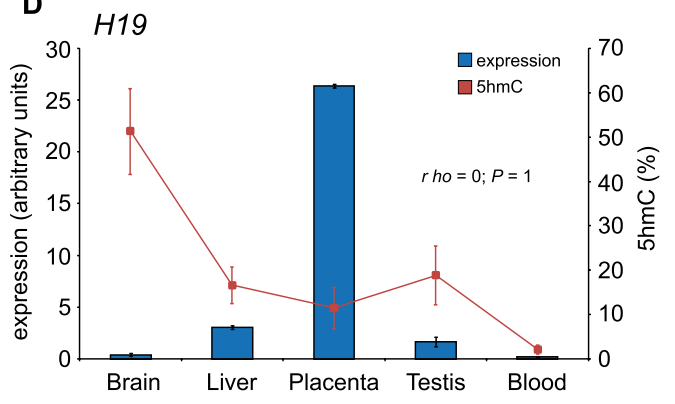

IGF2

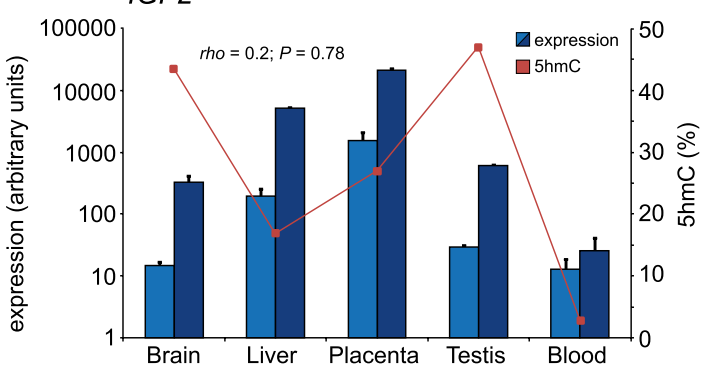

Figure 5. Tissue type is a major modifier of $5 \mathrm{hmC}$ levels in genes. ( $A$ ) Unsupervised hierarchical clustering of 12 loci by absolute $5 \mathrm{hmC}$ levels results in two groups containing high (HIGH) and low (LOW) levels of $5 \mathrm{hmC}$, respectively, for each indicated tissue. (Red boxes) $H 19 / / G F 2$ loci; (blue boxes) $H O X A$ loci. (B) Box-plot of $5 \mathrm{hmC}(\%)$ levels of all five loci in the HIGH cluster for each tissue shows that the range of $5 \mathrm{hmC}$ levels at HIGH loci varies markedly between tissues. (C) The relative global $5 \mathrm{hmC}$ content (Fig. 1C) correlates with average $5 \mathrm{hmC}$ (\%) content of each tissue as determined by $5 \mathrm{hmC}$-qPCR. (D) Inter-tissue differences in $5 \mathrm{hmC}$ levels do not correlate with inter-tissue expression levels. Average $5 \mathrm{hmC}$ (\%) content of genic loci of $H 19$ (upper panel) and IGF2 (lower panel) in each indicated tissue is plotted against expression of probes (H19=1 probe; IGF2 = 2 probes) for each gene obtained from the GNF expression database. The GNF expression database does not contain data for breast.

have the highest levels of $5 \mathrm{hmC}$ and highly proliferative tissues and cell lines would contain the least, as is broadly observed (Fig. 1C). Indeed, adaptation of normal breast cells to culture conditions did result in a decrease in $5 \mathrm{hmC}$ levels over time, consistent with an increase in passive loss of $5 \mathrm{hmC}$ due to an increased proliferation rate in culture (Fig. 2E). However, a simultaneous downregulation of TET1/2/3 gene expression was also observed, suggesting that the reduction in $5 \mathrm{hmC}$ was due to both passive loss and reduced production of $5 \mathrm{hmC}$ (Fig. 2C,E). Irrespective of the mechanism of TET repression and $5 \mathrm{hmC}$ loss in culture, this finding highlights the marked difference in $5 \mathrm{hmC}$ biology between cell lines and their tissues of origin. Further study of the loss of $5 \mathrm{hmC}$ upon transformation of tissues to cell culture may offer a useful tool in dissecting $5 \mathrm{hmC}$ biology in mammals.

We also report a dramatic reduction of global $5 \mathrm{hmC}$ levels and TET1/2/3 gene expression in breast cancer cell lines compared with normal breast tissue (Fig. 2A-D). This observation is particularly interesting, given that breast cancer cell lines possess extensive aberrant promoter hypermethylation, and these promoters are enriched for CpG Island promoters marked simultaneously by H3K4me3 and H3K27me3 (bivalent promoters) in ES cells, the same class of genes identified as being marked by TET1 occupancy in mouse ES cells (Ohm et al. 2007; Sproul et al. 2011; Williams et al. 2011).

In summary, our results reveal that tissue type is a major modifier of both global and locus-specific $5 \mathrm{hmC}$ at genes in normal human tissues, suggesting that the functional importance of $5 \mathrm{hmC}$ varies between tissues. We also show that cell culture is refractory to both TET1/2/3 gene expression and maintenance of global $5 \mathrm{hmC}$ content. Our study emphasizes the importance of the model system (tissue or cell line) used to study $5 \mathrm{hmC}$ and the pressing need for more practicable quantitative assays of $5 \mathrm{hmC}$.

\section{Genome Research}




\section{Methods}

\section{Ethics statement}

The use of human breast materials from the Edinburgh Breast Unit at the Western General Hospital was approved by the Lothian Research Ethics Committee (08/S1101/41).

\section{DNA, RNA, and tissue samples}

Normal human tissue DNA samples were purchased from AMS Biotechnology Ltd. unless stated otherwise. Normal human tissue RNA samples were purchased from Applied Biosystems. SHEF-6 human embryonic stem cell DNA and RNA was a kind gift from Dr. David Hay (Center for Regenerative Medicine, Edinburgh, UK) (Aflatoonian et al. 2010). Clinical specimens of normal human breast tissue were obtained through the Edinburgh Experimental Cancer Medicine Center. Sample details are given in Supplemental Table S1. DNA and RNA were isolated from cell lines using the QIAGEN AllPrep DNA/RNA/Protein Mini Kit.

\section{Cell culture}

All human breast cancer cell lines were cultured as per Neve et al. (2006). HepG2, HCT116, and SW480 cells were cultured in DMEM, McCoys 5A and Leibovitz's L-15 medium, respectively, supplemented with $10 \%$ fetal calf serum (FCS). Human mammary epithelial cell (HMEC) lines were established from normal human breast tissue as previously described (Holliday et al. 2009). Subsequently, HMECs were maintained in CnT22 medium (CellnTEC) supplemented with $10 \%$ FCS.

\section{DNA dot-blotting}

DNA samples were added to denaturation buffer $(0.4 \mathrm{mM} \mathrm{NaOH}$, $10 \mathrm{mM}$ EDTA) and denatured for $10 \mathrm{~min}$ at $100^{\circ} \mathrm{C}$. Samples were rapidly chilled for $5 \mathrm{~min}$ on wet ice and then applied to a positively charged nylon membrane under vacuum using a 96-well Dot Blot Hybridisation Manifold (Harvard Apparatus Limited). The membrane was washed twice in $2 \times$ SSC buffer, UV-cross-linked, and dried for $1 \mathrm{~h}$ at $70^{\circ} \mathrm{C}$. Duplicate membranes were probed with antibodies specific to $5 \mathrm{mC}$ (Eurogenentec; dilution factor 1:2000) and $5 \mathrm{hmC}$ (Active Motif; dilution factor 1:8000). To control for loading, duplicate membranes were probed with a rabbit polyclonal antibody raised against single-stranded DNA (Demeditec Diagnostics). Subsequently, membranes were probed with either a rabbit $(\alpha-5 \mathrm{hmC}$ and $\alpha$-ssDNA membranes) or mouse $(\alpha-5 \mathrm{mC}$ membranes) IgG antibody conjugated to horseradish peroxidase (HRP). Following treatment with enhanced chemiluminescence (ECL) substrate, membranes were scanned on an ImageQuant LAS 4000 (GE Healthcare) imaging station. Spot intensity was quantified using ImageJ image processing and analysis software (NIH).

\section{Immunoprecipitation and genomic mapping} $5 \mathrm{mC}$ - and $5 \mathrm{hmC}$ - containing DNA fragments

Genomic DNA (5hmC-IP; $2.5 \mu \mathrm{g}$ in $450 \mu \mathrm{L}$ of TE), sonicated to yield a fragment distribution of $\sim 300-1000 \mathrm{bp}$, was denatured by incubation for $10 \mathrm{~min}$ at $100^{\circ} \mathrm{C}$. Samples were rapidly chilled on wet ice. At this point, $45 \mu \mathrm{L}(10 \%)$ of denatured sample was removed and saved as input, and $45 \mu \mathrm{L}$ of $10 \times$ IP buffer $(100 \mathrm{mM} \mathrm{Na}$ Phosphate at pH 7.0 [mono and dibasic], $1.4 \mathrm{M} \mathrm{NaCl}, 0.5 \%$ Triton $\mathrm{X}-100$ ) and $1 \mu \mathrm{g}$ of $\alpha-5 \mathrm{hmC}$ (ActiveMotif; \#39769) antibody were added to the remaining sample. Samples were incubated overnight at $4^{\circ} \mathrm{C}$ with gentle agitation. Then, $40 \mu \mathrm{L}$ of magnetic beads (Dynabeads Protein G; Invitrogen) in $1 \times$ IP buffer was added to each sample to allow magnetic separation of the antibody from the unbound DNA using a magnetic tube rack. Samples were incubated for $1 \mathrm{~h}$ at $4^{\circ} \mathrm{C}$ with gentle agitation. Beads were collected with a magnetic rack and washed with $1000 \mu \mathrm{L}$ of $1 \times$ IP buffer for $10 \mathrm{~min}$ at room temperature with gentle agitation; washing was repeated three times. Beads were collected with a magnetic rack and resuspended in $250 \mu \mathrm{L}$ of digestion buffer $(50 \mathrm{mM}$ Tris at $\mathrm{pH}$ 8.0, $10 \mathrm{mM}$ EDTA, $0.5 \%$ SDS) followed by addition of $10 \mu \mathrm{L}$ of proteinase K (20 mg/mL; Roche Applied Science) and incubation for $1.5 \mathrm{~h}$ at $52^{\circ} \mathrm{C}$ with constant shaking ( $\geq 800 \mathrm{rpm}$ ). Finally, beads were removed using a magnetic rack, and DNA was purified from the remaining sample using a QIAquick PCR Purification Kit (QIAGEN), eluting in a final volume of $40 \mu \mathrm{L}$ of $\mathrm{dH}_{2} \mathrm{O}$. Inputs were also purified using a QIAquick PCR Purification Kit and eluted in $40 \mu \mathrm{L}$ of $\mathrm{dH}_{2} \mathrm{O}$.

Subsequently, $10 \mathrm{ng}$ of input and IP DNA was subjected to whole genome amplification (WGA) using the GenomePlex Complete Whole Genome Amplification Kit (Sigma-Aldrich) as per the manufacturer's instructions. Amplified DNA was run on a $1.2 \%$ agarose gel to confirm consistency of fragment size between samples. Subsequently, amplified DNA samples were Cy5- (IP) or Cy3(Input) labeled by random priming using the Dual-Color DNA Labeling Kit (NimbleGen). Labeled samples were applied to a Human DNA Methylation 4x72K ENCODE HG17 Targeted Tiling Array, which tiles the biologically significant ENCODE regions (EN001-EN014), and hybridized overnight at $42^{\circ} \mathrm{C}$. Slides were washed and scanned as per the NimbleGen protocol.

\section{Analysis of microarray data}

All analysis of NimbleGen microarray data was performed using custom-written scripts implemented in the statistical programming language R. Due to differences in the saturation kinetics of the dyes used to label the input and IP samples, the absolute enrichment values of a probe $(\mathrm{M})$ often show a dependency on the average intensity of the probe across the input and IP (A). To correct for this bias, each array was subjected to locally weighted scatterplot smoothing (Loess normalization) (Cleveland 1979). Subsequently, scale normalization was used to normalize values of $\mathrm{M}$ between arrays of replicate samples. Finally, the data were smoothed using a running median in a sliding window of 13 probes. A peak of $5 \mathrm{hmC}$ was defined as any region of five consecutive probes in which at least four probes had an enrichment value greater than the 75th percentile. This definition of a peak resulted in a false discovery rate of 0.017 . All R-scripts are available upon request. Although the microarrays were designed against the hg17 version of the human genome assembly, all coordinates were mapped to version hg18 to allow comparison with RNA-sequencing data. Conversion of genomic coordinates between genome assemblies was performed using the "liftOver" tool downloaded from the UCSC Genome Browser.

Previously published RNA-sequencing data for normal human breast, brain, colon, liver, and testis were downloaded from the UCSC Genome Browser (Ramskold et al. 2009). RNA-seq data were used in their normalized form expressed as reads per million (RPM). Probes were designated as in a transcribed region if they overlapped a sequencing read by one or more base pairs. Where the density of reads overlapping a probe varied across the length of the probe, the average density was used.

\section{Absolute quantification of 5 -hmC and 5-mC levels at specific CpG dinulceotides}

Absolute levels of $5 \mathrm{hmC}, 5 \mathrm{mC}$, and $\mathrm{C}$ at specific $\mathrm{MspI}$ sites were quantified using the EpiMark 5-hmC and 5-mC Analysis Kit 
(\#E3317S; New England BioLabs) followed by quantitative PCR (qPCR). An outline of the assay and sample calculations are presented in Supplemental Figure S1. Briefly, DNA is treated with T4 $\beta$-glucosyltransferase (T4-BGT), which specifically glucosylates 5 -hydroxymethylcytosine to yield $\beta$-glucosyl-5hmC (5ghmC). Whereas MspI is capable of cleaving its recognition sequence containing either $5 \mathrm{mC}$ (C5mCGG) or 5hmC (C5hmCGG), cleavage is blocked by $5 \mathrm{ghmC}$ (C5 ghmCGG). qPCR is used to determine the amount of DNA template cut by MspI before and after treatment with T4-BGT, allowing estimation of the absolute $5 \mathrm{hmC}$ levels at the MspI site. The oligonucleotide primer sequences used are listed in Supplemental Table S2A.

\section{RNA extraction, cDNA synthesis, and quantitative reverse transcriptase PCR}

RNA was extracted from cell lines using TRIzol reagent (Invitrogen) or an RNeasy Mini kit (QIAGEN) according to the manufacturers' instructions. A Superscript II Reverse transcriptase kit (Invitrogen) was used to make complementary DNA from $500 \mathrm{ng}$ of total RNA. All qRT-PCRs were carried out at an annealing temperature $58^{\circ} \mathrm{C}$ in a LightCycler 480 Real-Time PCR System (Roche Applied Science). Primer sequences are given in Supplemental Table S2B.

\section{Data access}

All microarray data have been submitted to the NCBI Gene Expression Omnibus (GEO) (http://www.ncbi.nlm.nih.gov/geo/) under accession number GSE33219.

\section{Acknowledgments}

We thank Tobias Straub and Johannes Soding for R-scripts and advice concerning the analysis of NimbleGen tiling array data. Thanks to Dr. James Hackett for help with development of the $5 \mathrm{hmC}-\mathrm{IP}$ technique and advice and Dr. John Thomson for helpful discussions. Thanks to Lorna Renshaw (Edinburgh Breast Unit) for assistance with obtaining breast materials. We acknowledge the support of Cancer Research UK for the Edinburgh Cancer Research Centre. This work was funded by the Breakthrough Breast Cancer and the Medical Research Council.

\section{References}

Aflatoonian B, Ruban L, Shamsuddin S, Baker D, Andrews P, Moore H. 2010 Generation of Sheffield (Shef) human embryonic stem cell lines using a microdrop culture system. In Vitro Cell Dev Biol Anim 46: 236-241.

Bird A. 2002. DNA methylation patterns and epigenetic memory. Genes Dev 16: 6-21.

Borgel J, Guibert S, Li Y, Chiba H, Schubeler D, Sasaki H, Forne T, Weber M. 2010. Targets and dynamics of promoter DNA methylation during early mouse development. Nat Genet 42: 1093-1100.

Chen DT, Nasir A, Culhane A, Venkataramu C, Fulp W, Rubio R, Wang T, Agrawal D, McCarthy SM, Gruidl M, et al. 2010. Proliferative genes dominate malignancy-risk gene signature in histologically-normal breast tissue. Breast Cancer Res Treat 119: 335-346.

Cleveland W. 1979. Robust locally weighted regression and smoothing scatterplots. I Am Stat Assoc 74: 829-836.

Dahl C, Gronbaek K, Guldberg P. 2011. Advances in DNA methylation: 5-hydroxymethylcytosine revisited. Clin Chim Acta 412: 831-836.

Davis T, Vaisvila R. 2011. High sensitivity 5-hydroxymethylcytosine detection in Balb/C brain tissue. J Vis Exp e2661. doi: 10.3791/2661.

Ehrlich M, Gama-Sosa MA, Huang LH, Midgett RM, Kuo KC, McCune RA, Gehrke C. 1982. Amount and distribution of 5-methylcytosine in human DNA from different types of tissues of cells. Nucleic Acids Res 10: 2709-2721.

Esteller M. 2007. Cancer epigenomics: DNA methylomes and histonemodification maps. Nat Rev Genet 8: 286-298.
Ficz G, Branco MR, Seisenberger S, Santos F, Krueger F, Hore TA, Marques CJ, Andrews S, Reik W. 2011. Dynamic regulation of 5-hydroxymethylcytosine in mouse ES cells and during differentiation. Nature 473: 398-402.

Figueroa ME, Abdel-Wahab O, Lu C, Ward PS, Patel J, Shih A, Li Y, Bhagwat N, Vasanthakumar A, Fernandez HF, et al. 2010. Leukemic IDH1 and IDH2 mutations result in a hypermethylation phenotype, disrupt TET2 function, and impair hematopoietic differentiation. Cancer Cell 18: 553-567.

Globisch D, Munzel M, Muller M, Michalakis S, Wagner M, Koch S, Bruckl T, Biel M, Carell T. 2010. Tissue distribution of 5-hydroxymethylcytosine and search for active demethylation intermediates. PLOS ONE 5: e15367. doi: 10.1371/journal.pone.0015367.

Hajkova P, Erhardt S, Lane N, Haaf T, El-Maarri O, Reik W, Walter J, Surani MA. 2002. Epigenetic reprogramming in mouse primordial germ cells. Mech Dev 117: 15-23.

Holliday DL, Brouilette KT, Markert A, Gordon LA, Jones JL. 2009. Novel multicellular organotypic models of normal and malignant breast: tools for dissecting the role of the microenvironment in breast cancer progression. Breast Cancer Res 11: R3. doi: 10.1186/bcr2218.

Huang Y, Pastor WA, Shen Y, Tahiliani M, Liu DR, Rao A. 2010. The behaviour of 5-hydroxymethylcytosine in bisulfite sequencing. PLoS ONE 5: e8888. doi: 10.1371/journal.pone.0008888.

Iqbal K, Jin SG, Pfeifer GP, Szabo PE. 2011. Reprogramming of the paternal genome upon fertilization involves genome-wide oxidation of 5-methylcytosine. Proc Natl Acad Sci 108: 3642-3647.

Ito S, D'Alessio AC, Taranova OV, Hong K, Sowers LC, Zhang Y. 2010. Role of Tet proteins in $5 \mathrm{mC}$ to $5 \mathrm{hmC}$ conversion, ES-cell self-renewal and inner cell mass specification. Nature 466: 1129-1133.

Jin SG, Kadam S, Pfeifer GP. 2010. Examination of the specificity of DNA methylation profiling techniques towards 5-methylcytosine and 5-hydroxymethylcytosine. Nucleic Acids Res 38: e125. doi: 10.1093/nar/ gkq223.

Jin SG, Wu X, Li AX, Pfeifer GP. 2011. Genomic mapping of 5 -hydroxymethylcytosine in the human brain. Nucleic Acids Res 39: 5015-5024.

Kinney SM, Chin HG, Vaisvila R, Bitinaite J, Zheng Y, Esteve PO, Feng S, Stroud H, Jacobsen SE, Pradhan S. 2011. Tissue-specific distribution and dynamic changes of 5-hydroxymethylcytosine in mammalian genomes. J Biol Chem 286: 24685-24693.

Koh KP, Yabuuchi A, Rao S, Huang Y, Cunniff K, Nardone J, Laiho A, Tahiliani M, Sommer CA, Mostoslavsky G, et al. 2011. Tet1 and Tet2 regulate 5-hydroxymethylcytosine production and cell lineage specification in mouse embryonic stem cells. Cell Stem Cell 8: 200-213.

Kriaucionis S, Heintz N. 2009. The nuclear DNA base 5-hydroxymethylcytosine is present in Purkinje neurons and the brain. Science 324: 929-930.

Li E, Bestor TH, Jaenisch R. 1992. Targeted mutation of the DNA methyltransferase gene results in embryonic lethality. Cell 69: 915-926.

Lock LF, Takagi N, Martin GR. 1987. Methylation of the Hprt gene on the inactive $X$ occurs after chromosome inactivation. Cell 48: 39-46.

Lorsbach RB, Moore J, Mathew S, Raimondi SC, Mukatira ST, Downing JR. 2003. TET1, a member of a novel protein family, is fused to MLL in acute myeloid leukemia containing the $\mathrm{t}(10 ; 11)(\mathrm{q} 22 ; \mathrm{q} 23)$. Leukemia 17: 637641.

Mayer W, Niveleau A, Walter J, Fundele R, Haaf T. 2000. Demethylation of the zygotic paternal genome. Nature 403: 501-502.

Nestor C, Ruzov A, Meehan R, Dunican D. 2010. Enzymatic approaches and bisulfite sequencing cannot distinguish between 5-methylcytosine and 5-hydroxymethylcytosine in DNA. Biotechniques 48: 317-319.

Neve RM, Chin K, Fridlyand J, Yeh J, Baehner FL, Fevr T, Clark L, Bayani N, Coppe JP, Tong F, et al. 2006. A collection of breast cancer cell lines for the study of functionally distinct cancer subtypes. Cancer Cell 10: 515527.

Ohm JE, McGarvey KM, Yu X, Cheng L, Schuebel KE, Cope L, Mohammad HP, Chen W, Daniel VC, Yu W, et al. 2007. A stem cell-like chromatin pattern may predispose tumor suppressor genes to DNA hypermethylation and heritable silencing. Nat Genet 39: 237-242.

Oswald J, Engemann S, Lane N, Mayer W, Olek A, Fundele R, Dean W, Reik W, Walter J. 2000. Active demethylation of the paternal genome in the mouse zygote. Curr Biol 10: 475-478.

Pastor WA, Pape UJ, Huang Y, Henderson HR, Lister R, Ko M, McLoughlin EM, Brudno Y, Mahapatra S, Kapranov P, et al. 2011. Genome-wide mapping of 5-hydroxymethylcytosine in embryonic stem cells. Nature 473: 394-397.

Plass C, Soloway PD. 2002. DNA methylation, imprinting and cancer. Eur J Hum Genet 10: 6-16.

Ramskold D, Wang ET, Burge CB, Sandberg R. 2009. An abundance of ubiquitously expressed genes revealed by tissue transcriptome sequence data. PLoS Comput Biol 5: e1000598. doi: 10.1371/journal.pcbi.1000598.

Richardson AL, Wang ZC, De Nicolo A, Lu X, Brown M, Miron A, Liao X, Iglehart JD, Livingston DM, Ganesan S. 2006. X chromosomal abnormalities in basal-like human breast cancer. Cancer Cell 9: 121-132.

\section{Genome Research}


Sado T, Fenner MH, Tan SS, Tam P, Shioda T, Li E. 2000. X inactivation in the mouse embryo deficient for Dnmt1: Distinct effect of hypomethylation on imprinted and random X inactivation. Dev Biol 225: 294-303.

Song CX, Szulwach KE, Fu Y, Dai Q, Yi C, Li X, Li Y, Chen CH, Zhang W, Jian $\mathrm{X}$, et al. 2010. Selective chemical labeling reveals the genome-wide distribution of 5-hydroxymethylcytosine. Nat Biotechnol 29: 68-72.

Sproul D, Nestor C, Culley J, Dickson JH, Dixon JM, Harrison DJ, Meehan RR, Sims AH, Ramsahoye BH. 2011. Transcriptionally repressed genes become aberrantly methylated and distinguish tumors of different lineages in breast cancer. Proc Natl Acad Sci 108: 4364-4369.

Szwagierczak A, Bultmann S, Schmidt CS, Spada F, Leonhardt H. 2010. Sensitive enzymatic quantification of 5-hydroxymethylcytosine in genomic DNA. Nucleic Acids Res 38: e181. doi: 10.1093/nar/gkq684.

Tahiliani M, Koh KP, Shen Y, Pastor WA, Bandukwala H, Brudno Y, Agarwal S, Iyer LM, Liu DR, Aravind L, et al. 2009. Conversion of 5-methylcytosine to 5-hydroxymethylcytosine in mammalian DNA by MLL partner TET1. Science 324: 930-935.

Turashvili G, Bouchal J, Baumforth K, Wei W, Dziechciarkova M, Ehrmann J, Klein J, Fridman E, Skarda J, Srovnal J, et al. 2007. Novel markers for differentiation of lobular and ductal invasive breast carcinomas by laser microdissection and microarray analysis. BMC Cancer 7: 55. doi: 10.1186/1471-2407-7-55.

Valinluck V, Sowers LC. 2007. Endogenous cytosine damage products alter the site selectivity of human DNA maintenance methyltransferase DNMT1. Cancer Res 67: 946-950.

Valinluck V, Tsai HH, Rogstad DK, Burdzy A, Bird A, Sowers LC. 2004. Oxidative damage to methyl-CpG sequences inhibits the binding of the methyl-CpG binding domain (MBD) of methyl-CpG binding protein 2 (MeCP2). Nucleic Acids Res 32: 4100-4108.
Walsh CP, Chaillet JR, Bestor TH. 1998. Transcription of IAP endogenous retroviruses is constrained by cytosine methylation. Nat Genet 20: 116117.

Weisenberger DJ, Campan M, Long TI, Kim M, Woods C, Fiala E, Ehrlich M, Laird PW. 2005. Analysis of repetitive element DNA methylation by MethyLight. Nucleic Acids Res 33: 6823-6836.

Williams K, Christensen J, Pedersen MT, Johansen JV, Cloos PA, Rappsilber J, Helin K. 2011. TET1 and hydroxymethylcytosine in transcription and DNA methylation fidelity. Nature 473: 343-348.

Wossidlo M, Nakamura T, Lepikhov K, Marques CJ, Zakhartchenko V, Boiani M, Arand J, Nakano T, Reik W, Walter J. 2011. 5-Hydroxymethylcytosine in the mammalian zygote is linked with epigenetic reprogramming. Nat Commun 2: 241. doi: 10.1038/ncomms1240.

Wu SC, Zhang Y. 2010. Active DNA demethylation: Many roads lead to Rome. Nat Rev Mol Cell Biol 11: 607-620.

Wu H, D'Alessio AC, Ito S, Wang Z, Cui K, Zhao K, Sun YE, Zhang Y. 2011a. Genome-wide analysis of 5-hydroxymethylcytosine distribution reveals its dual function in transcriptional regulation in mouse embryonic stem cells. Genes Dev 25: 679-684.

Wu H, D'Alessio AC, Ito S, Xia K, Wang Z, Cui K, Zhao K, Sun YE, Zhang Y. 2011b. Dual functions of Tet1 in transcriptional regulation in mouse embryonic stem cells. Nature 473: 389-393.

Xu W, Yang H, Liu Y, Yang Y, Wang P, Kim SH, Ito S, Yang C, Xiao MT, Liu LX, et al. 2011. Oncometabolite 2-hydroxyglutarate is a competitive inhibitor of $\alpha$-ketoglutarate-dependent dioxygenases. Cancer Cell 19: 17-30.

Received May 18, 2011; accepted in revised form November 10, 2011. 


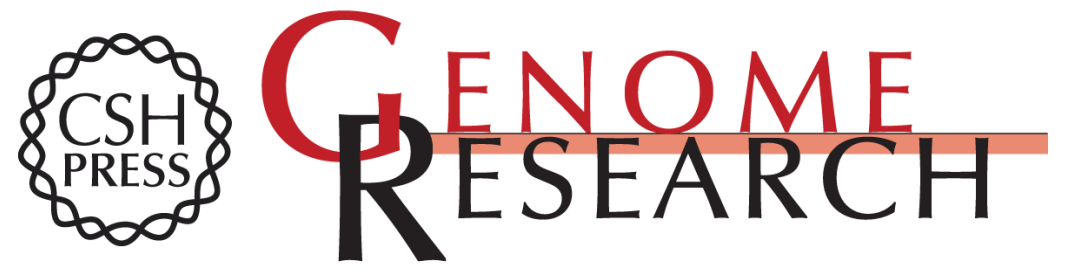

\section{Tissue type is a major modifier of the 5-hydroxymethylcytosine content of human genes}

Colm E. Nestor, Raffaele Ottaviano, James Reddington, et al.

Genome Res. 2012 22: 467-477 originally published online November 21, 2011

Access the most recent version at doi:10.1101/gr.126417.111

Supplemental Material

References This article cites 49 articles, 8 of which can be accessed free at: http://genome.cshlp.org/content/22/3/467.full.html\#ref-list-1

Open Access Freely available online through the Genome Research Open Access option.

License Freely available online through the Genome Research Open Access option.

Email Alerting
Service $\begin{aligned} & \text { Receive free email alerts when new articles cite this article - sign up in the box at the } \\ & \text { top right corner of the article or click here. }\end{aligned}$

\section{Affordable, Accurate Sequencing.}

